\title{
The Effects of the Strength of Family of Origin and Self-Differentiation on Teacher-Infant Relationships
}

\author{
Hyun Soon Park ${ }^{1}$, Joo Hyun Suh ${ }^{2}$ \\ Ph. D. Student, Department of Family Welfare, Sangmyung University, Seoul, Korea ${ }^{1}$ \\ Assistant Professor, Department of Family Welfare, Sangmyung University, Seoul, Korea ${ }^{2}$ \\ 보육교사의 원가족 건강성과 자아분화가 교사-영아 간 \\ 긍정적/부정적 관계에 미치는 영향 \\ 박현순 ${ }^{1}$, 서주현 ${ }^{2}$ \\ 상명대학교 가족복지학과 석·박 수료 ${ }^{1}$ 상명대학교 가족복지학과 조교수 ${ }^{2}$
}

Objectives: The purpose of this research is to examine the effects of the strength of family of origin and self-differentiation on teacher-infant relationships. Teachers can establish an attachment with infants by influencing them in an important way, just as the family does. Based on the results of previous studies that investigated the effect of mothers' strength of family of origin and selfdifferentiation on parent-child relationships, we investigated the effects of the strength of origin and self-differentiation on teacher-child relationships.

Methods: A total of 198 teachers from childcare centers in Seoul and Gyeonggi Province answered the questionnaires. A stepwise multiple regression analysis was used to analyze data.

Results: In teacher-infant relationships, intimate relationships in positive relationships were found to be correlated with a higher level of health in the original family, and in relationships of conflict; the lower the self-differentiation, the more influential the strength of the family of origin. Close relationships in negative relationships in teacher-infant relations did not show any meaningful explanatory power. In relationships of conflict, the lower the self-differentiation, the more influential the strength of the family of origin.

Conclusions: Teachers are in an important position to establish relationships with infants; their relationships with infants can be predicted to affect overall development. For the teacher-infants relationship to be stable, it is necessary to prepare a program that allows teachers to reconstruct the children's difficulties in a positive way in order to resolve difficulties arising from the original family and improve self-separation.

Keywords: the strength of family of origin, self-differentiation, teacher-infant relationships

\section{Introduction}

영아기는 생애에 가장 중요한 발달과업을 이루어야하는 시기

Corresponding Author: Joo Hyun Suh, Assistant Professor, Department of Family Welfare, Sangmyung University, 20, Hongjimun 2-gil, Jongno-gu, Seoul, Korea

E-mail: jhsuh@smu.ac.kr
이다. 특히 주양육자와 건강한 관계를 형성하며 주양육자의 온정적이고 민감한 양육을 받을 때, 정서적으로 안정된 가운 데 최적의 발달을 이루며 성장할 수 있다. 영아기 주양육자는

(C)The Korean Association of Child Studies

This is an Open Access article distributed under the terms of the Creative Commons Attribution Non-Commercial License (http:// creativecommons.org/licenses/by-nc/4.0) which permits unrestricted noncommercial use, distribution, and reproduction in any medium, provided the original work is properly cited. 
전통적으로 어머니를 비롯한 가족 내 구성원이 주를 이루어왔 다. 그러나 현대사회는 가족구조가 점차적으로 변화되었고 부 모의 맞벌이가 보편화되면서 점차 영아의 양육에 대한 책임이 영유아 보육 또는 교육기관으로 옮겨지고 있다. 특히 영아의 어린이집 이용이 꾸준히 증가하던 우리나라는 2013년 무상 보육이 전면적으로 실시되었다. 이후, 영아의 어린이집 이용 이 급속히 증가하였다. 연령별 보육아동 현황을 국가통계포털 에 따르면 전체 보육아동 중에서 만0세 만2세까지의 영아가 $59.45 \%$ 의 높은 비중을 차지하고 있다(Ministry of Health and Welfare, 2017). 출생 후 주양육자와 안정애착을 형성하며 발달 해야 하는 영아들이 부모의 품을 벗어나 어린이집에 맡겨지는 사례가 증가하고 있으며 그 시기 또한 점점 빨라지고 있는 것 이다. 영아는 태어나면서 주양육자에 의해 받아야하는 민감하 고 안정적인 양육을 새로운 환경인 어린이집에서 보육교사로 부터 받아야 한다. 이러한 상황은 영아를 맡은 보육교사가 보 육업무를 수행할 때에 영아와의 안정애착 형성을 통한 긍정적 인 관계를 형성해야 한다. 또한 영아가 건강하게 발달 및 성장 할 수 있도록 돕는 주양육자로서의 역할을 감당해야 할 필요 성과 그 역할의 중요성을 부각시키고 있다.

원가족 건강성은 개인이 성장한 가족 안에서 자율과 친밀 한 관계를 지각하고 느끼는 정도를 의미한다 $(\mathrm{Ha}, 2007)$. 영아 는 모의 태내에서부터 출생하고 가족 안에서 양육을 받으며 영아기와 아동기를 거쳐 성장을 하게 된다. 성장기에 부모로 부터 받은 긍정적 경험은 이후 정서와 대인관계 그리고 행동 방식을 결정짓는 역할을 하고(Vondra, Sysko, \& Belsky, 2005), 원가족에서 부모와의 애착경험은 자녀를 양육할 때 중요한 변 인으로 나타난다(Bowlby, 1958). 어머니가 어린 시절 경험했 던 원가족에 대한 지각은 자신의 자녀와 상호작용할 때에 영 향을 미칠 수 있는 관계가 있는 것으로 나타났다(I. H. Choi, 2012). 또한 자녀를 양육하고 있는 어머니가 애착을 형성했던 자신의 어머니와의 애착경험에 대한 경험을 안정적으로 지각 할 경우 자녀인 영아에 대한 높은 애착을 가지고 양육을 하게 된다(Hwang \& Chung, 2006). 또한 정서적으로 안정되고 건강 한 원가족에서 자란 부모는 자신의 자녀에게 올바른 양육태도 로 부모역할을 긍정적으로 할 수 있는 것으로 나타났다(Huh, 2011). 반면 양육자인 어머니가 지각하고 있는 자신의 성장기 에 경험한 원가족에서의 경험이 좋지 않았을 경우 그러한 경 험이 자녀를 양육할 때 스트레스의 원인이 되는 것으로 나타 났다(J. A. Song, 2018).

이러한 연구결과는 개인이 성장기에 경험한 정서적인 건강 은 부모가 되었을 때 자녀를 양육하는 태도에 영향을 미칠 수
있는 것으로, 양육자는 자신의 원가족에서의 경험을 바탕으로 자녀를 양육하게 되므로 양육의 경험은 세대 간 전이가 나타 난다고 해석할 수 있다. 보육교사는 부모를 대신하여 어린이 집에서 언어 발달이전의 시기로 울음과 몸짓 그리고 옹알이로 자신을 표현하고 있는 영아를 돌보아야 한다. 그러므로 보육 교사 자신이 성장기에 경험하여 지각하고 있는 원가족 건강성 의 정도는 교사가 영아와 관계를 맺을 때에 영향을 미칠 수 있 는 중요한 변인으로 기능할 것을 예측할 수 있다.

기존의 원가족 건강성에 대한 연구를 살펴보면, 주로 부모 혹은 주양육자인 어머니의 원가족 경험이 자녀 양육행동에 미 치는 영향에 관련한 연구(H. K. Hong, 2016; J.-H. Jeon, 2009; S. J. Song, 2015)와 부모와 자녀 간 관계에 관련한 연구(B.-S. Cho \& Choi, 2013; S.-W. Jang, 2008)들이 있다. 그러나 보육교사의 원가족 경험에 관한 연구는 거의 이루어져 있지 않고 있다. 보 육교사는 자신의 원가족에서 긍정적·부정적인 경험을 하며 성장하였고 그 경험이 교사의 정서 발달에 영향을 미쳤을 것 으로 예측할 수 있다. 그러므로 보육교사가 경험한 원가족건 강성이 교사와 영아 간 관계에 미치는 영향에 대해 살펴보는 것은 매우 중요하고 볼 수 있다.

자아분화는 개인이 자신의 사고와 감정을 분리시키고 가 족으로부터 개별화될 수 있는 정도를 의미하며 개인에 대한 특성으로 내적인 차원과 관계적인 차원을 포함한다(Kerr \& Bowen, 1988). 또한 개인이 올바른 대인관계를 형성하고 발달 을 건강하게 이루기 위해서는 원가족 안에서의 분화가 건강 하게 이루어져야 한다(Anderson \& Sabatelli, 1992). 일반적으 로 스트레스를 받는 상황에서는 자아분화의 수준이 높을수록 효율적으로 대처를 할 수 있고 자아분화의 수준이 낮을수록 현실을 직면하지 않고 회피하거나 부정적인 감정을 표현하는 것으로 행동을 이어간다(Lazarus, 1981). 또한 개인의 감정에 의해 객관적으로 구별하지 못하고 충동에 의한 반응을 한다 (Bekker \& van Assen, 2006). 이러한 연구 결과는 자아분화 수준 이 높을수록 외부의 자극에 민감하지 않고 정서가 안정될 수 있는 것으로 해석할 수 있다. 자아분화가 제대로 이루어지지 못할 경우에는 자신의 감정 안에서 사고를 분리시키기 어렵고 객관적인 사고를 수행하기 어려울 수 있다. 사고와 감정의 균 형이 이루어 졌을 때에 충동적인 경험을 하게 되는 상황이 발 생하게 되어도 처해진 문제 안에서 해결을 하는 자제력을 발 휘 할 수 있다. 정서적으로 안정된 개인으로 발달하기 위해서 는 감정 안에서 자신의 사고를 건강하게 분리할 수 있도록 원 가족에서의 긍정적인 경험이 반복적으로 이루어져야 하는 것 이다. 
어머니의 자아분화의 수준에 따라 자녀를 양육하며 스트 레스 상황에 직면하게 되었을 때에 이를 해결하기 위한 노력 을 하는 정도에 차이가 있다( J. Y. Oh, 2016). 또한 부모의 자아 분화 수준이 높을수록 문제 발생 시 자녀에 대해 부정적인 감 정과 부정적인 행동을 적게 하는 것으로 나타났다(H.-K. Lee \& Lee, 2011). 자녀를 양육하는 어머니는 자아분화 수준이 높 을수록 자녀와 개방적이며 긍정적인 의사소통을 한다(M. H.

Kim, 2014; J. Y. Lim, 2011; M. J. Park, 2011).

이처럼 어머니의 자아분화 수준이 자녀 양육에 영향을 미치 고 영아를 양육하는 주양육자의 자아분화 수준은 자녀와의 관 계를 연결하는 의사소통에도 영향을 미친다. 이러한 선행연구 들의 결과를 바탕으로 유추할 때, 영아의 양육을 담당하는 보 육교사의 자아분화 수준 역시 보육교사가 영아를 보육할 때에 영향을 미칠 수 있는 중요한 변인이 될 것으로 예측할 수 있다.

보육교사는 발달과업을 이루며 성장해야하는 시기의 영아 를 돌보되 정서적으로는 안정이 되고 건강한 발달이 이루어지 도록 보육해야 하는 중요한 역할을 담당하고 있다. 그러나 어 린이집에서 영아를 담임하고 있는 보편적인 보육교사의 일과 는 하루 종일 장시간동안 이루어지는 영아를 돌보는 보육업 무와 그 외의 업무분장에 의한 개인 업무를 추가적으로 해야 한다. 영아 관찰 및 보육일지작성 그리고 보육환경관리 등 수 행해야 할 일들이 산재해있는 실정이다. 이러한 과도한 업무 시간 및 업무량은 보육교사로 하여금 여러 가지 심리적인 스 트레스를 받을 수 있는 환경을 제공한다. 정서지능이 높은 보 육교사는 보육업무에 의한 스트레스를 지각하는 정도가 낮다 (M. S. Song \& Kim 2009). 영아를 담임하고 있는 보육교사 또 한 자녀를 양육하는 어머니와 유사한 양상으로 자아분화의 수 준에 따라 스트레스 상황에서 자신의 정서를 조절하여 반응하 는 행동의 표현이 다를 수 있다. 그러므로 보육교사의 자아분 화의 수준이 영아를 보육하는 데에 있어 교사의 행동과 정서, 의사소통에 영향을 미쳐 교사가 영아와 관계를 맺을 때 정서 적으로 안정된 애착을 형성하는데 영향을 미치는 중요한 요인 이 될 것으로 예측을 할 수 있다. 그러나 지금까지 살펴본 연구 에서는 보육교사의 자아분화 수준이 영아와의 관계에 미치는 영향에 대한 연구는 거의 이루어지지 않고 있다. 그러므로 본 연구에서는 보육교사의 자아분화가 교사와 영아간의 관계에 미치는 영향에 대해 살펴보고자 한다.

영아는 어린이집에서 가족 외의 성인인 보육교사와 밀접 한 관계를 맺게 된다. 영유아는 주양육자와 안정 애착을 형성 하고 건강한 관계를 내재화하고 있을 때 환경에 잘 적응할 수 있고 사회 안에서 건강한 성장을 할 수 있으며(J. A. Oh, 2007),
성장기에 부정적으로 경험하여 내재된 정서는 성인이 되어 관 계의 어려움을 야기시킨다(Halford, Sanders, \& Behrens, 2001). 영아는 주양육자와의 관계에서와 같이 교사와의 관계를 긍 정적으로 인식하게 될 때 교사를 자신의 안전기지로 삼아 더 개방적으로 자신을 표현하게 된다(J. Y. Moon, 2014). Bowlby (1969)는 자녀가 성장하면서 부모로부터 대우를 받은 경험이 타인에 대해 형성하게 되는 관계의 표상이 된다고 하였다. 또 한 부모와 안정된 애착을 경험하면 자신과 타인에 대해 긍정 적이게 되고 부모와 애착을 불안정하게 경험하면 자신과 타인 에 대해 부정적으로 세상을 반영한다(Bowlby, 2008). 그러므로 영아가 부모와 맺는 애착유형이 긍정적이고 부정적인 것에 따 라 타인과의 관계에 영향을 미친다(B.-S. Cho \& Choi, 2013). 또한 선행연구(M.-S. Choi, Kong, \& Park, 2012)에 따르면 어 머니가 자녀와 긍정적인 관계를 맺고 자녀와의 관계를 긍정 적으로 평가할 경우에 유아의 문제행동이 감소되며, 어머니 의 긍정적, 부정적 양육태도는 자녀의 정서조절과 관련된다 (H. S. Lim \& Park, 2002). 반대로 주양육자가 자녀와 부정적인 관계를 맺게 될수록 유아의 문제행동이 높게 나타난다(K. O. Hong, 2001). 생애초기에 보육시설에서 오랜 시간을 보내는 영아에게 있어서 보육교사는 가족과 같이 주요한 영향을 미치 는 관계이며 영아는 교사와 애착 관계를 형성하게 되므로 교 사와 영아 간 긍정적인 관계를 형성하는 것이 영아발달에 영 향을 미치게 된다(H. S. Park \& Suh, 2017). 보육교사와 영아가 형성한 애착의 경험이 학령기의 또래 관계에 많은 영향을 미 친다(Howes, Hamilton, \& Philipsen, 1998)는 연구는 교사와 영 아 간의 관계의 질은 영아의 발달에 있어 매우 중요하며 교사 와 영아 간 관계는 한 개인의 대인관계에 영향을 미치는 요인 이 되는 것을 시사한다.

여타의 인간관계가 그러하듯이 교사-영아 간 관계에도 교 사가 지각하기에 긍정적인 상호작용을 주로 하는 영아와의 관 계가 있는가 하면 부정적인 상호작용을 많이 하는 영아와의 관계도 있다. 특히 보육할 때에 교사의 대응하는 방법에 따라 영아가 정서조절을 하는 방법이 다르다(Power, 2004). 그러므 로 발달 특성에 맞는 영아와 교사와의 관계는 개별적인 일대 일의 대응관계가 가장 이상적이며 이러한 관계가 이루어지도 록 노력을 해야 한다. 따라서, 교사-영아 간 학급 전체를 생각 하며 평정하는 것은 교사와 영아 간 관계의 실제를 반영하는 데에는 근본적인 한계가 있다. 그러므로 교사와 영아 간 관계 역시 개별 영유아와의 관계를 기반으로 긍정적인 관계와 부 정적인 관계로 나누어 살펴볼 필요가 있다. 긍정적 관계는 양 자 간 긍정적인 상호작용을 통해 긍정적 정서를 경험하는 관 
계를 뜻하며 부정적 관계는 이와 상반되는 부정적 상호작용을 통해 부정적 정서를 경험하는 관계이다. 교사의 긍정적인 상 호작용과 민감한 반응은 유아의 정서에 긍정적인 영향을 준 다(Kochanska, 2002). 그리고 선행연구(M.-S. Choi et al., 2012; K. O. Hong, 2001)에 따르면 부모-자녀관계에서 긍정적 관계 와 부정적 관계는 자녀의 발달에 각기 다른 영향을 미친다. 그 러므로 교사와 영아 간의 관계의 질과 그것이 미치게 될 영향 에 대하여서도 양자 간의 관계에서 긍정적인 상호작용을 반복 적으로 경험하고 있는지, 부정적인 상호작용을 반복적으로 경 험하고 있는지에 따라 영향요인이 다르게 나타날 것을 예측할 수 있다. 그러나 선행연구들(Ju, 2015; J. S. Lee, 2001; M. Y. Lee, 2014; E.-S. Moon \& Kim, 2011; S.-M. Park, 2013)은 교사가 학 급의 아동들과의 맺고 있는 전반적인 관계에 대한 평가로 대 신하여, 개별 영아들과 맺는 보다 실제적인 관계의 양상을 보 기 어렵다는 단점이 있다. 그러므로 본 연구에서는 교사가 영 아와 맺는 관계를 실제적 관계에 기반하여 교사가 지각하는 가장 긍정적인 관계를 맺고 있는 영아와 가장 부정적인 관계 를 맺고 있는 영아와의 관계로 구분하고 각각의 관계의 양상 을 측정하여 보다 면밀히 살펴보고자 한다. Pianta와 Steinberg (1992)는 교사가 맺는 유아와의 관계를 관계 안에서의 친밀 감과 갈등 그리고 의존으로 구분하여 설명하였다(Hamre \& Pianta, 2001). 본 연구에서는 교사와 영아 간 관계에서 교사가 지각하기에 가장 긍정적 상호작용을 하는 영아와의 관계를 교 사 영아 간 긍정적 관계로, 교사가 지각하기에 가장 부정적 상 호작용을 하는 영아와의 관계를 부정적 관계로 조작적으로 정 의하여 각 관계에서 느끼는 친밀감, 갈등정도, 의존정도를 하 위요인으로 나누어 살펴보고자 한다.

선행연구들에 따르면, 관계의 친밀감 수준에 따라 교사와 영아간의 개방적인 의사소통과 온정적으로 보육하는 환경의 차이가 있으며, 친밀한 관계는 정서적으로 안정감을 주고 영 아는 자신감을 가지게 된다(J. S. Lee, 2001). 관계의 갈등 수준 에 따라서도 다른 영향을 미친다. 갈등 수준이 높으면 교사와 영아 간에 상호작용이 적절하게 이루어지지 못하며 어린이 집에 대해 부정적인 문제행동이 나타난다(Bridget \& Robert, 2001). 관계의 의존정도는 영아가 주양육자에 의존하던 것에 서 비롯하여 보육교사 등의 상대방에게 지나치게 의지하는 관 계를 나타낸다(Hamre \& Pianta, 2001). 의존성은 교사에게 지 나치게 의존하는 유아의 행동이며(Birch \& Ladd, 1998), 의존 성이 높은 유아는 또래와의 관계가 어려운 것으로 나타났다 (Sroufe \& Fleeson, 1986). 이처럼 관계의 하위 영역인 친밀감, 갈등, 의존 정도에 따라 관계의 양상과 이로 인한 영향력이 상
이함을 알 수 있다.

이상의 논의를 바탕으로 본 연구는 생애발달에서 매우 기 초적이고 중요한 역할을 하는 영아기 발달에 있어 주양육자로 서의 어머니의 책임이 보육교사로 옮겨진 우리 사회의 현실을 반영하고자 한다. 또한 부모의 원가족 건강성 및 자아분화가 부모-자녀관계에 미치는 영향을 고찰했던 관련 선행연구결과 들을 기반으로 하여 현대사회에서 중요성이 부각되고 있는 보 육교사의 교사-영아관계로 확장시키고자 한다. 이에 본 연구 는 교사의 원가족 건강성과 자아분화가 교사-영아 간 관계에 미치는 영향력을 살펴보고 관계의 특성을 면밀히 살펴보기 위 하여 긍정적인 관계와 부정적인 관계의 차이를 검증하고 각각 의 관계에서의 영향요인을 도출하고자 한다. 이를 통해 도출 된 결과는 보육현장에서의 교사와 영아 간 관계가 보다 안정 되고 긍정적인 관계를 형성 할 수 있도록 돕는 개입의 방향을 제시하는데 중요한 자료가 될 것이다.

이상의 목적으로 설정된 연구문제는 다음과 같다.

\section{연구문제 1}

보육교사가 지각하는 교사-영아 간 긍정적/부정적 관계에 따 라 관계의 하위영역(친밀관계, 갈등관계, 의존관계)은 차이가 있는가?

\section{연구문제 2}

보육교사의 원가족 건강성과 자아분화, 교사-영아 간 긍정적/ 부정적 관계(친밀관계, 갈등관계)는 어떠한 관계가 있는가?

\section{연구문제 3}

보육교사의 원가족 건강성과 자아분화는 교사-영아 간 긍정 적 관계(친밀관계, 갈등관계)에 어떠한 영향을 미치는가?

\section{연구문제 4}

보육교사의 원가족 건강성과 자아분화는 교사-영아 간 부정 적 관계(친밀관계, 갈등관계)에 어떠한 영향을 미치는가?

\section{Methods}

\section{연구대상}

서울과 경기도의 어린이집에서 영아를 담임하고 있는 250 명 의 보육교사를 대상으로 설문조사를 실시하였다. 보육교사 
Table 1

General Characteristics of Teachers

\begin{tabular}{|c|c|c|c|}
\hline & & Frequency $(n)$ & $\%$ \\
\hline \multirow{5}{*}{ Age } & $20 s$ & 46 & 23.2 \\
\hline & $30 s$ & 30 & 15.2 \\
\hline & $40 s$ & 97 & 49.0 \\
\hline & Over 50 s & 18 & 9.1 \\
\hline & Non-response & 7 & 3.5 \\
\hline \multirow[t]{5}{*}{ Academic background } & High school graduation & 41 & 20.7 \\
\hline & College graduate & 87 & 43.9 \\
\hline & University graduate & 56 & 28.3 \\
\hline & More than a graduate school & 7 & 3.5 \\
\hline & Non-response & 7 & 3.5 \\
\hline \multirow[t]{4}{*}{ Infant homeroom teacher experience } & 1 to 3 years later & 105 & 53.0 \\
\hline & 3 to 5 years later & 37 & 18.7 \\
\hline & More than 5 years & 44 & 22.2 \\
\hline & Non-response & 12 & 6.1 \\
\hline \multirow[t]{4}{*}{ Childcare employment history } & 1 to 3 years later & 81 & 40.9 \\
\hline & 3 to 5 years later & 38 & 19.2 \\
\hline & More than 5 years & 68 & 34.3 \\
\hline & Non-response & 11 & 5.6 \\
\hline
\end{tabular}

Note. $N=198$.

의 성별은 모두 여성이며, 원가족 건강성 및 자기분화 그리 고 교사-영아 간 관계의 각 자기보고식 설문에서 결측치가 있 는 설문(사회 인구학적 배경의 결측지는 제외)을 제외하고 총 198 명을 연구대상으로 선정을 하였다. 사회인구학적변인은 Table 1과 같다. 교사의 연령은 40 대가 $49 \%(97$ 명)로 가장 많았 으며 30 대 이하에서 $38.4 \%(76$ 명)로 나타났다. 학력으로는 전 문대 졸 $43.9 \%(87$ 명)와 4 년제 졸 $28.3 \%$ (56명)로 거의 대부분 의 학력이 전문대 졸 이상으로 나타났다. 영아반 담임을 한 경 력은 3년 미만이 $53.0 \%(105$ 명)로 과반수이상이 되었다. 보육 교사로 근무를 한 총 경력은 1-3년 미만이 40.9\%(81명)로 가 장 많은 것으로 나타났고 다음으로 경력 5년 이상의 경우가 $34.3 \%(68$ 명)로 나타났다.

\section{연구도구}

\section{원가족 건강성}

원가족 건강성에 대한 척도는 Havestadt 등(1985)이 제작한 Family of Origin Scale (FOS)을 바탕으로 하여 한국 가족의 정 서에 적합하도록 개발한 후 타당도와 신뢰도를 검증한 Choi
(1997)의 원가족척도(the Family of Origin Scale-55 [FOS-55]) 중에서 J.-H. Jeon (2009)이 원가족척도의 전체 55문항 중 16 문 항에서 원가족에 대한 인식의 전반적인 건강성을 측정하는 것 에 대해 높은 설명력으로 나타나 타당성이 검증된 척도를 사 용하였다. 이 척도는 원가족에서 친밀한 관계가 북돋워지고 자율정도를 나타내며, 자신의 원가족 건강성을 어떻게 지각하 고 있는지 알아보는 자기 보고식 질문지이다. 원가족 건강성 을 측정하는 내용은 “우리 가정에서 나의 감정은 무엇이든 표 현할 수 있었다." 그리고 "가족 앞에서 나의 의견을 자유롭게 표현 하였다.” 등이다. 신뢰도 계수(Cronbach's $\alpha$ )는 .93이다.

\section{자기분화}

자기분화수준 척도는 Y. J. Jeon (2002)이 Bray, Williamson 과 Malone (1984)의 Personal Authority in the Family System Questionnaire (PAFS-Q)와 Jeon (1984)의 자아분화 척도 그리고 Chun (1996)의 부모-자녀 분화 척도(Parnt-Child Differentiation Scale [PCDS])를 토대로 개발한 원가족 분화경험척도를 사용 하였다. 이 척도는 정서적 단절과 삼각화는 점수가 낮을수록 분화수준이 높음을 의미하고 정서적 분리는 점수가 높을수록 
분화 수준이 높음을 의미하기 때문에 자기분화수준과 일관되 게 하기 위하여 각 하위변인의 방향성을 통일하였다. 그러므 로 정서적 단절과 삼각화의 점수는 역채점한 값 $(\mathrm{K} . \mathrm{H} . \mathrm{Kim} \&$ Kim, 2016, as cited in H. S. Park \& Suh, 2017) 전체를 합산 및 평균하여 사용을 하였다. 자기분화는 그 점수가 높을수록 분 화수준이 높음을 의미하는 것으로 개인이 원가족에서 독립하 기 이전에 부모와 정서적 관계를 어떠하게 경험하였는가를 알 아보는 자기 보고식 질문지이다. 자기분화를 측정하는 내용 은 "내가 어릴 때 우리 집보다 더 편한 느낌을 주는 집이 있었 다.”, "어머니(아버지)는 나 때문에 아버지(어머니)와 싸우셨 다.” 등이다. 신뢰도 계수(Cronbach's $\alpha$ )는 .90이다.

\section{교사-영아 간 관계}

영아와 교사 간 관계 척도는 Pianta (1991)의 교사와 영아간의 관계에 대해 교사의 지각용 평가도구인 유아-교사관계 척도 (Student-Teacher Relationship Scale [STRS], Pianta, 1991)를 J. S. Lee (2001)가 수정 및 보완한 척도를 사용하였다. 이 척도는 유 아에게서 나타나는 정서적인 반응과 행동에 대한 교사의 지각 및 유아에 대한 교사의 느낌과 같은 관계적인 영역을 알아보 는 자기 보고식 질문지이다. 교사-영아 간 관계의 친밀감, 갈 등정도, 의존정도를 측정한다. 일반적으로 지난 4 주간의 영아 와의 관계를 떠올리며 평가하도록 요구하는 형식이다. 그러나 척도를 사용할 때에 학급에서 어떠한 영아를 두고 평가를 할 것인지에 대한 뚜렷한 기준이 없다. 그러므로 본 연구에서는 교사-영아 간 관계에서 교사가 느끼고 있는 것에서 긍정적 정 서를 지각하는 영아와 부정적 정서를 지각하는 영아로 나누어 각각에 대한 관계의 양상을 구체적으로 평정하였다. 교사-영 아 간 관계를 측정하는 내용은 "이 아이는 나와의 관계를 중요 하게 생각한다." 그리고 "이 아이는 나와 잘 떨어지려고 하지 않는다.” 등이다. 긍정적/부정적 관계의 각 하위영역(친밀, 갈 등)별로 신뢰도 계수(Cronbach's $\alpha$ )는 .820 .849이다.

\section{연구절차}

본 연구에서는 사용할 도구들의 신뢰도와 타당도를 조사하기 위하여 예비조사를 실시하였다. 검사를 위하여 경기도 파주시 소재의 어린이집에서 근무를 하고 있는 보육교사 가운데 연구 의 대상인 영아를 담임하고 있는 보육교사 20 명을 대상으로 검증하였으며, 예비조사에서 설문에 대하여 명확한 구조화를 통한 설명을 구성하여 척도에 대한 신뢰도와 타당도를 높였
다. 이어 본 조사는 서울과 경기도의 어린이집 중 영아반이 있 는 기관을 대상으로 질문지를 배부하고 교사들의 응답을 받아 직접 수거하였다. 서울 160 부, 경기도 180 부 총 340 부의 질문 지를 배부하여 총 250 부가 회수되었다. 이 중 결측치가 있는 설문지 52 부를 제외한 198 부를 분석에 사용하였다.

\section{자료분석}

수집된 자료의 분석은 IBM SPSS 21.0 (IBM Co., Armonk, NY) 을 사용하여 빈도, 백분율, 평균, 표준편차, Pearson의 적률상관 관계를 산출하였다. 교사-영아 간 관계의 긍정적/부정적 관계 의 차이를 검증하기 위해 paired $t$-test를 사용하였고, 원가족 건 강성과 자기분화가 보육교사와의 교사-영아 간 긍정적/부정 적 관계에 미치는 영향을 알아보기 위해 SPSS 21.0 (IBM Co., Armonk, NY)을 이용하여 단계적 중다회귀분석을 실시하였 다.

\section{Results}

\section{교사-영아 간 긍정적 관계와 부정적 관계의 차이}

교사-영아 간 관계의 긍정적 관계와 부정적 관계에서의 차이 를 살펴보고자 각 관계의 하위 영역별로 paired $t$-test를 하였다. 그 결과는 Table 2 와 같다. 교사-영아 간 관계의 하위요인인 친 밀관계 $(M=.560, S D=.564)$ 에서는 긍정관계와 부정관계가 통 계적으로 유의한 차이가 나타났다 $(t=13.978, p<.001)$. 교사영아 간 관계의 하위요인인 갈등관계 $(M=-.635, S D=.675)$ 에 서도 긍정관계와 부정관계가 통계적으로 유의한 차이가 나타 났다 $(t=-13.220, p<.001)$. 이러한 결과는 교사-영아 간 관계 에 있어서 교사가 지각한 영아와의 관계가 긍정적일 때와 부 정적일 때, 교사-영아 간 관계의 하위영역인 친밀도나 갈등정 도에서 차이가 있음을 통계적으로 입증한 결과로서 교사-영 아 간 관계를 하위요인(친밀관계와 갈등관계)으로 나뉘어 세 부적으로 살펴 볼 필요가 있음을 시사한다. 교사-영아 간 관계 의 하위요인인 의존관계에서는 유의한 차이가 나타나지 않았 다. 이는 발달특성상 주 양육자에 대한 의존적 상호작용이 많 은 영아기의 특성이 반영된 결과로 해석된다.

이러한 결과에 기반하여 본 연구는 교사-영아 간 관계를 긍 정적 관계와 부정적 관계로 나누어 각 하위요인 중 친밀관계 와 갈등관계를 살펴보고자 한다. 
Table 2

Differences Between Positive Relationships and Negative Relationships

\begin{tabular}{|c|c|c|c|c|}
\hline \multicolumn{2}{|c|}{ Teacher-infant relationships } & $M$ & $S D$ & $t$ \\
\hline \multirow[t]{2}{*}{ Intimacy } & Positive & 4.052 & .489 & $13.978^{* * *}$ \\
\hline & Negative & 3.492 & .580 & \\
\hline \multirow[t]{2}{*}{ Conflict } & Positive & 1.839 & .574 & $-13.220^{* * *}$ \\
\hline & Negative & 2.473 & .661 & \\
\hline \multirow[t]{2}{*}{ Dependency } & Positive & 2.897 & .800 & 1.422 \\
\hline & Negative & 2.806 & .754 & \\
\hline
\end{tabular}

Note. $N=198$.

${ }^{* * *} p<.001$.

Table 3

Correlations Between the Strength of Family of Origin, Self-Differentiation, Teacher-Infant Positive Relationships and Teacher-Infant Negative Relationships

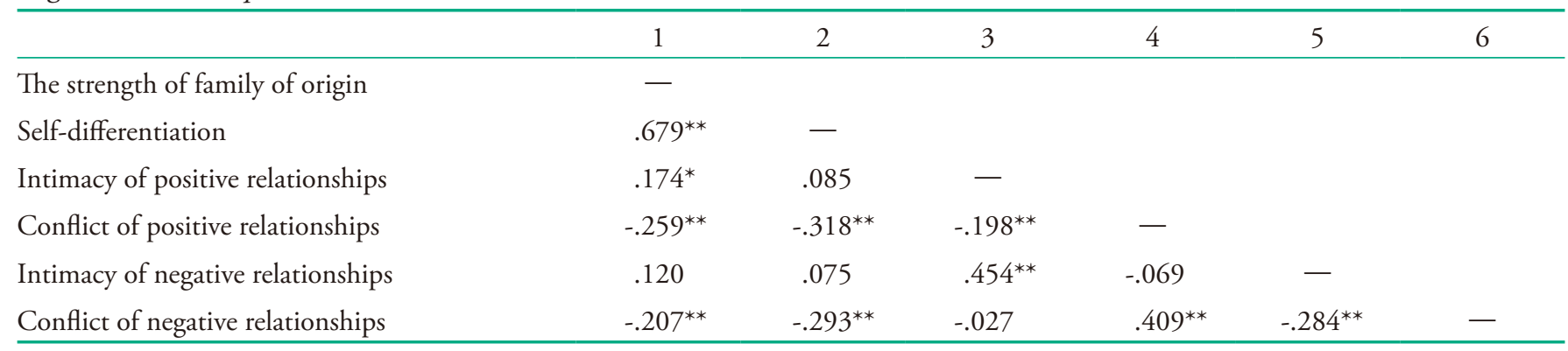

Note. $N=198$.

${ }^{*} p<.05 .{ }^{* *} p<.01$.

\section{원가족 건강성 및 자기분화와 교사-영아 간 관계의 상관관계}

원가족 건강성과 자기분화가 교사-영아 간 관계에 미치는 영 향을 알아보기 위해 Pearson의 적률상관관계수를 산출하였으 며, 그 결과는 Table 3 과 같다. 상관계수는 교사-영아 간 관계의 하위영역 중 영아와의 긍정적 관계에서의 친밀관계는 긍정적 관계에서의 갈등관계와 유의한 부적인 상관관계가 있었고 $(r$ $=-.198, p<.01)$, 원가족 건강성과 유의한 정적인 상관관계 $(r=$ $.174, p<.05)$ 가 있었다. 교사-영아 간 관계의 하위영역 중 긍정 적 관계에서의 갈등관계는 또한 원가족 건강성과 유의한 부적 인 상관관계가 있었고 $(r=-.259, p<.01)$ 과 자기분화와도 유의 한 부적인 상관관계가 있었다 $(r=-.318, p<.01)$.

교사-영아 간 관계의 하위영역 중 영아와의 부정적 관계에 서의 친밀관계는 긍정적 관계에서의 친밀도와 유의한 정적인 상관관계를 보였으나 $(r=-.318, p<.01)$ 원가족 건강성 및 자기 분화와는 유의한 상관관계가 나타나지 않았다. 교사-영아 간
부정적 관계에서의 갈등관계는 원가족 건강성 $(r=-.207, p<$ $.01)$ 및 자기분화 $(r=-.293, p<.01)$ 와 유의한 부적인 상관관계 가 있었고, 부정적 관계에서의 친밀도와도 유의한 부적인 상 관관계를 보였다 $(r=-.284, p<.01)$. 긍정적 관계의 갈등관계와 는 유의한 정적인 상관관계를 나타냈다 $(r=.409, p<.01)$.

\section{원가족 건강성 및 자기분화가 교사-영아 간 긍정적 관계에 미치는 영향}

원가족 건강성 및 자기분화가 긍정적 관계의 친 밀도에 미치는 영향

교사-영아 간 긍정적 관계의 하위요인인 친밀도에 대한 원가 족 건강성과 자기분화의 상대적 영향력을 파악하기 위해 단계 적 중다회귀분석을 실시하였다. 그 결과는 Table 4 와 같다. 보 육교사와 영아 간 긍정적 관계의 친밀도에 대한 보육교사의 원가족 건강성과 자기분화의 영향력을 검증한 결과, 원가족 
Table 4

Effect of the Strength of Family of Origin and Self-Differentiation on the Intimacy of Positive Teacher-Infant Relationships

\begin{tabular}{lccccc}
\hline Independent variable & $B$ & $\beta$ & $t$ & $R^{2}$ & $F$ \\
\hline Constant & 3.529 & & & .030 & $6.120^{*}$ \\
The strength of family of origin & .138 & .174 & $2.474^{*}$ & & \\
\hline
\end{tabular}

Note. $N=198$.

${ }^{*} p<.05$.

Table 5

Effect of the Strength of Family of Origin and Self-Differentiation on the Conflict of Positive Teacher-Infant Relationships

\begin{tabular}{lcccc}
\hline Independent variable & $B$ & $\beta$ & $t$ & $R^{2}$ \\
Constant & 3.146 & & & \\
Self-differentiation & -.337 & -.318 & $-4.697^{* * *}$ & .101 \\
\hline
\end{tabular}

Note. $N=198$.

*** $p<.001$.

건강성 $(\beta=.174, p<.05)$ 이 $3 \%$ 의 설명력을 갖는 요인으로 나 타났다 $(F=6.120, p<.05)$. 자기분화는 설명 변인에서 제외되 었다. 이 결과는 교사-영아 간 긍정적 관계에서의 친밀도에 영 향을 미치는 요인은 원가족 건강성으로서 보육교사의 원가족 건강성이 높을수록 교사-영아 간 긍정적 관계에서의 친밀도 가 높아진다는 것을 나타낸다.

원가족 건강성 및 자기분화가 교사-영아 간 긍 정적 관계의 갈등정도에 미치는 영향

교사-영아 간 긍정적 관계의 하위요인인 갈등 정도에 대한 원 가족 건강성과 자기분화의 상대적 영향력을 단계적 중다회귀 분석으로 검증한 결과는 Table 5 와 같다. 보육교사와 영아와 의 긍정적 관계의 갈등정도에 대한 보육교사의 원가족 건강성 과 자기분화 중 유효한 영향력을 미치는 변인은 자기분화 $(\beta=$ $-.318, p<.001)$ 로 나타났으며 자기분화의 설명력은 $10.1 \%$ 였 다 $(F=6.120, p<.05)$. 교사-영아 간 긍정적 관계의 친밀도와 는 달리, 갈등 정도에는 원가족 건강성은 유효한 영향력을 미 치지 못했다. 이 결과는 교사-영아 간 긍정적 관계의 친밀도에 영향을 미치는 요인은 자기분화로, 보육교사가 원가족과 자기 분화를 잘 이루었을수록 교사-영아 간 긍정적 관계에서의 갈 등정도가 낮아지는 것을 의미한다.

\section{원가족 건강성 및 자기분화가 교사-영아 간 부정적 관계에 미치는 영향}

원가족 건강성 및 자기분화가 부정적 관계의 친 밀도에 미치는 영향

교사-영아 간 부정적 관계의 하위요인인 친밀도에 대한 원가 족 건강성과 자기분화의 상대적 영향력을 단계적 중다회귀분 석으로 검증한 결과, 교사-영아 간 부정적 관계에서의 친밀도 에는 원가족 건강성과 자기분화가 모두 유의한 영향을 미치지 않는 것으로 나타났다. 이는 교사-영아 간 긍정적 관계와는 상 이한 결과로서 교사의 원가족 건강성이 영아와의 긍정적 관계 에서는 친밀도를 증가시키는 요인이나 부정적인 관계를 형성 한 영아와 교사의 관계에서는 친밀도에 긍정적 영향을 미치지 못함을 보여주는 결과이다.

원가족 건강성 및 자기분화가 부정적 관계의 갈 등정도에 미치는 영향

교사-영아 간 부정적 관계의 하위요인인 갈등 정도에 대한 원 가족 건강성과 자기분화의 상대적 영향력을 파악하기 위해 단 계적 중다회귀분석을 실시한 결과는 Table 6과 같다. 보육교사 와 영아 간 부정적 관계의 갈등 정도에 대해 유의한 영향력을 미치는 변인은 보육교사의 원가족 건강성과 자기분화 중 자기 분화 $(\beta=-.293, p<.001)$ 인 것으로 나타났으며 이 때 자기분화 의 설명력은 $8.6 \%$ 였다 $(F=18.463, p<.001)$. 원가족 건강성은 유효한 영향력을 미치지 못했다. 이 결과는 교사-영아 간 부정 적 관계의 갈등정도에 영향을 미치는 요인은 자기분화로, 보 
Table 6

Effect of the Strength of Family of Origin and Self-Differentiation on the Conflict of Negative Relationships

\begin{tabular}{lcccc}
\hline Independent variable & $B$ & $\beta$ & $t$ & $R^{2}$ \\
\hline Constant & 3.862 & & & .086 \\
Self-differentiation & -.358 & -.293 & $-4.297^{* * *}$ & $18.463^{* * *}$ \\
\hline
\end{tabular}

Note. $N=198$.

*** $p<.001$.

육교사가 원가족과 자기분화를 잘 이루었을수록 교사-영아 간 부정적인 관계에서의 갈등정도가 낮아지는 것을 의미한다.

\section{Discussion}

본 연구에서는 보육교사를 대상으로 보육교사의 원가족 건강 성과 자기분화가 교사-영아 간 긍정적, 부정적 관계에 어떠한 영향을 미치는지를 검증하였다. 연구결과를 토대로 한 논의는 다음과 같다.

첫째, 보육교사의 교사-영아 간 관계를 긍정적 관계와 부정 적 관계로 나누어 그 차이를 검증한 결과 교사-영아 간 긍정 적/부정적 관계의 하위요인인 친밀관계와 갈등관계에서 교사 와 영아의 긍정적 관계와 부정적 관계가 각각 통계적으로 유 의한 차이가 나타났다. 즉, 교사-영아 간 관계에 있어서 교사 가 영아와의 관계를 긍정적으로 지각하는 경우와 부정적으 로 지각하는 경우, 관계를 형성하는 하위 요인인 관계의 친밀 한 정도와 갈등정도에서 세부 양상이 다르다는 것을 보여준 다. 부모-자녀의 관계는 일대일(一對一)의 관계이나 후자는 일 대다(一對多)의 관계라는 차이점이 있다. 이에 따라 부모-자 녀 관계의 측정은 주로 해당 자녀와의 일대일의 관계에 대해 측정하나 교사-영아의 관계는 학급 전체 아이들과의 전반적 인 관계를 측정해 왔다. 본 연구는 교사-영아 간의 관계 측정 에 있어 교사가 학급 영아들 중 긍정적인 관계를 형성하고 있 는 경우와 부정적인 관계를 형성하고 있는 경우를 각각 측정 하여 각각의 관계에 미치는 보육교사의 원가족 건강성 및 자 아분화의 영향력을 검증하였는데, 긍정적 관계와 부정적 관계 에서 관계의 친밀도와 갈등정도가 차이가 있음을 통계적으로 입증한 위의 결과는 한 교사가 학급 내에서 맺는 관계의 속성 이 긍정적인 관계를 맺는 경우와 부정적인 관계를 맺는 경우 각각 다른 관계적 특성을 지닌다는 것을 나타낸다. 이러한 통 계결과를 바탕으로 본 연구에서는 긍정적, 부정적 관계를 나 누어 별개의 변인으로서 연구하였다. 교사와 교수대상자인 학 생의 관계를 측정한 선행연구들을 보면 초등학교 이상의 학생
들은 학생들이 교사와의 관계를 평정하는 연구들이 다수를 차 지하지만 영유아의 경우는 영유아가 평정을 하기는 어려움이 있기 때문에 교사가 영유아와의 관계를 평정한 연구들이 대부 분이다. 그러나 선행연구(J. B. Kim \& Kim, 2014)에서는 교사 와 학생이 평정하는 관계의 양상이 다르고, 교사가 제공한 관 계정보 역시 학생 개개인에 대한 교사의 생각이기 보다는 교 사가 학급 전체 혹은 일반적으로 지각하고 있는 학생의 정보 를 다루고 있다. 이와 같은 현상이 일어나는 가장 중요한 이유 는 연구의 실용성 측면에서 교사 개개인에게 자신이 가르치고 있는 모든 학생들 개개인에 대한 판단 정보를 제공하라고 요 구하는 것이 연구 현실상 어렵기 때문으로 해석한 바 있다. 본 연구는 교사와 영유아의 관계에 있어 영유아가 교사와의 관계 를 평정하기는 어렵기 때문에 교사로 하여금 개별적인 관계에 대해 평정하는 방식을 택하였으나 학급의 모든 영유아를 대상 으로 평정하지는 않았고 가장 긍정적인 관계와 가장 부정적 인 관계에 대한 평정을 통해 긍정적/부정적 관계의 양상을 살 펴보는 형식을 취하였다. 부분적인 시도이기는 하나 교사-영 아 간 관계를 보다 실제적으로 이해하기 위해서는 교사와 개 별 영아 간 관계의 특성을 고려할 수 있는 연구들이 확대되기 를 기대한다.

둘째, 보육교사의 원가족 건강성과 자기분화는 교사-영아 간 긍정적 관계의 친밀도와 유의한 정적인 상관관계가 있었 다. 이는 보육교사의 원가족 건강성과 자기분화 수준이 높은 경우 보육교사와 영아의 긍정적인 관계의 친밀도도 높은 경향 을 보인다고 볼 수 있으며, 건강한 원가족에서 정서적으로 안 정되게 성장한 부모는 자신의 자녀에게 긍정적으로 부모역할 을 한다고 한 연구(Huh, 2011)와 맥을 같이 하는 결과이다. 그 러나 교사-영아 간 부정적 관계의 친밀도는 원가족 건강성 및 자기분화와 유의한 상관관계가 없었다. 이는 보육교사가 부정 적으로 지각을 하고 있는 영아 간 관계에는 원가족 건강성과 자기분화의 영향력이 미치지 않는다는 관계의 차이를 보여주 는 결과이다. 교사-영아 간 긍정적 관계의 갈등과 관련하여서 는 교사-영아 간 긍정적 관계와 부정적 관계 모두에서 갈등정 도와 원가족 건강성 및 자기분화가 유의한 부적인 상관관계가 
있었다. 이는 보육교사의 원가족 건강성이 좋으며 자기분화 수 준이 높을 때, 영아를 보육하면서 갈등이 적은 경향성을 보인 다는 것이고 이를 해석하면 원가족 건강성이 높은 보육교사는 영아를 보육하면서 자신의 정서를 잘 조절하여 갈등이 덜 발생 하는 것으로 볼 수 있다. 이는 어머니가 원가족 건강성이 높고, 아동기 때 경험이 긍정적이며, 원가족의 정서적 분리가 건강할 수록 자녀를 지도할 때 합리적이며 애정적인 행동이 높게 나타 난 연구(Jeon, 2009) 및 어머니가 자신의 모와 안정적인 애착의 경험을 했을 경우 높은 애착을 가지고 영아를 양육하는 것으 로 나타난 연구(Hwang \& Chung, 2006)를 교사-영아 간 관계로 확장시켰을 때 같은 경향성을 나타내는 결과이다. 또한 부모의 원가족 경험이 부모와 자녀 간 상호작용에 서로 영향을 미치는 것으로 나타난 연구(I. H. Choi, 2012)의 결과가 교사-영아 간 관계에서도 같은 맥락으로 적용될 수 있다는 것을 보여준다. 보육교사의 높은 원가족 건강성이 영아와의 부정적 관계에서 의 친밀도를 제외한 긍정적, 부정적 관계에서의 높은 친밀도와 낮은 갈등정도에 관련된다는 결과는 높은 원가족 건강성이 교 사-영아 간 관계에 긍정적 기능을 할 수 있음을 나타낸다. 특히 교사-영아 간 관계의 갈등정도와 관련하여 긍정적 관계와 부 정적 관계 모두에서 높은 원가족 건강성과 자기분화가 낮은 갈 등정도와 관련됨으로써 이 두 변인이 영아와의 갈등정도를 낮 게 유지할 수 있는 변인임을 나타내었다.

셋째, 보육교사의 원가족 건강성과 자기분화가 교사-영아 간 긍정적 관계에 미치는 영향을 하위 요인별로 살펴본 결과, 긍정적 관계에서의 친밀도에 보육교사의 원가족 건강성이 영 향을 미치는 요인으로 나타났다. 즉, 교사의 원가족 건강성이 높을수록 교사-영아 간 긍정적인 관계의 친밀도가 높아진다 는 것이다. 이는 보육교사-영아 간 관계에서 긍정적인 관계를 맺고 있는 영아와의 친밀도에 미치는 영향은 자기분화 수준 보다 원가족에서의 경험을 긍정적으로 건강하게 지각하고 있 는 것이 중요한 요인임을 나타내는 것이다. 이러한 결과는 부 모-자녀 관계를 다룬 선행연구 결과에서 부모의 자기분화가 건강할 때 자녀와의 정서적 교감과 의사소통이 적절히 이루어 져 자녀의 정서지능에 영향을 미치며(A, 2016), 자기분화 수준 이 높은 어머니가 자녀와의 관계에서 문제발생시 정서로 대처 하는 방법을 덜 사용하는 연구결과(H.-K. Lee \& Lee, 2011; J.Y. Oh, 2016)와 일맥상통한다. 반면에 교사-영아 간 긍정적 관 계의 갈등정도에서는 교사의 자기분화가 높을수록 교사-영 아 간 긍정적 관계의 갈등정도가 낮아지는 것으로 나타났다. 이러한 결과는 양육을 하는 부모의 자아분화 수준이 높을수 록 개방적이며 긍정적인 의사소통을 하는 것으로 나타난 연구
(M. H. Kim, 2014; J. Y. Lim, 2011; M. J. Park, 2011)와 같은 맥 락으로 해석할 수 있다.

넷째, 보육교사의 원가족 건강성과 자기분화가 교사-영아 간 부정적 관계에 미치는 영향을 살펴본 결과 친밀도에서는 유의미한 설명력이 나타나지 않았다. 기존의 부모-자녀관계 에 대한 연구나 교사-영아 간 관계에 대한 연구들이 관계를 연 구함에 있어 대상과 긍정적인 관계를 형성하고 있는 경우와 부정적인 관계를 형성하고 있는 경우를 구분하여 살펴본 연구 가 없고 부정적인 관계에서의 친밀도의 양상에 대한 연구결 과가 없기 때문에 본 연구에서 제시된 교사-영아 간 부정적 관 계의 친밀도에 미치는 영향력에 대한 것을 기존의 연구결과와 함께 논의할 수는 없다. 그러나 어머니의 자아분화가 높을수 록 자녀에게 애정적, 자율적, 성취적, 합리적인 양육태도가 높 은 것으로 나타난 연구(J. Y. Moon, 2013)와 비교했을 때, 선행 연구 결과를 바탕으로 주양육자의 자아분화는 관계의 친밀도 를 높일 수 있는 요인으로 해석이 가능하나 관계를 긍정적인 관계와 부정적인 관계로 구분하여 살펴보았을 때에는 부정적 인 관계에서는 이러한 영향력을 미치지 못한다는 것을 보여주 는 결과라고 할 수 있다. 이는 긍정적인 관계에서와 부정적인 관계에서의 관련 변인의 양상이 다르게 나타났다는 점에서 유 아의 학교 적응에 미치는 영향력에 있어 교사와의 긍정적 관 계보다 교사-유아 간 갈등적 관계가 더 영향력이 크므로 교사유아 간 부정적 관계 맥락의 영향력을 별도로 살펴볼 필요가 있다고 한 연구(Birch \& Ladd, 1998)와 비교했을 때, 연구의 측 정방식의 차이는 있지만 긍정적/부정적 관계에 따라 관련변 인의 양상이 다르다는 점에서는 맥을 같이 한다고 볼 수 있다. 이처럼 본 연구에서는 부정적 관계에 영향을 미치는 관련변인 의 영향력 검증을 시도한 것에 의미가 있다. 부정적 관계에 미 치는 원가족 건강성과 자아분화의 영향력은 본 연구에서 교 사-영아 간 긍정적 관계의 친밀도에 미치는 영향력이 유의했 던 것과는 다른 양상으로서 원가족 건강성의 긍정적 영향력이 교사-영아 간 긍정적 관계에는 주효하나 부정적 관계에서의 친밀도를 높이지는 못한다는 것을 나타낸다. 이는 보육교사의 원가족 건강성이 높을수록 원가족에서의 긍정적 관계 및 친밀 한 관계의 경험을 바탕으로 영아와의 긍정적인 관계에서는 원 가족에서 경험한 것과 유사한 방식의 상호작용을 통해 친밀도 를 높이는 데에는 도움이 될 수 있다(Jeon, 2009). 그러나 보육 교사가 원가족에서 경험한 건강한 관계의 경험이 영아와의 부 정적인 관계에서는 건강한 상호작용을 적용할 수 없고 이에 따라 부정적인 관계의 친밀도를 높이는 데는 유효한 영향력을 미칠 수 없었던 것으로 해석할 수 있다. 이러한 결과를 감안할 
때, 보육교사와 영아 간의 긍정적 관계를 더욱 증진시키는 방 안과 부정적 관계를 감소시키는 방안은 동일한 방식으로 접근 하기보다 각각의 관계에 대한 특성을 파악하여 그에 맞는 개 입이 이루어져야 한다. 특히 부정적인 관계를 형성한 경우 이 에 대한 개입방식은 부정적 관계에서의 긍정적 상호작용을 증 진하는 방식의 교육 등 별도의 특화된 과정 및 프로그램의 개 발이 필요함을 시사한다.

교사-영아 간 부정적 관계의 갈등정도에 대해서는 긍정적 관계에서와 마찬가지로 교사의 자기분화가 높을수록 교사-영 아 간 부정적인 관계의 갈등정도가 낮아지는 것으로 나타났 다. 이러한 결과는 부모의 자아분화 수준이 높을수록 부정적 인 감정과 부정적인 행동을 적게 하는 것으로 나타난 결과(H.K. Lee \& Lee, 2011)와 같은 맥락이다. 즉 보육교사가 영아와 부정적인 관계를 맺고 있을 때 교사-영아 간 관계의 갈등정도 에 보육교사의 자기분화가 보호요인으로 작용할 수 있다는 것 을 보여준다.

보육교사는 영아와 오랜 시간을 함께 보내며 영아와 지속 적인 관계를 맺고 발달에 영향을 미치는 중요한 타인으로서 영아와 함께 있으며 상호작용하고 그들의 욕구를 이해하고 수 용해 주어야 하는 역할을 맡고 있다. 이러한 지속적인 상호작 용을 통해 교사와 영아는 안정적인 애착 관계를 형성할 수 있 다. 그러므로 보육교사와 영아의 관계에서 보다 긍정적인 상 호작용이 이루어짐으로써 안정적으로 애착형성이 이루어지 고 긍정적인 관계를 증진하며 부정적인 관계를 개선하기 위 한 개입은 매우 중요하다. 본 연구의 결과에 기반할 때, 보육교 사는 자신이 경험한 원가족의 건강성과 관련하여 그로 인하여 내재화된 정서적인 어려움을 해결할 수 있도록 돕고 자기분화 수준을 높여주는 효율적인 방안이 필요하다. 이는 긍정적 관 계의 교사-영아 간 친밀도를 높이고 갈등정도를 낮추며, 부정 적인 관계의 갈등정도를 낮추는 개입이 될 것이다. 그러므로 보육교사를 위한 개입방법으로 교사가 자신의 원가족에서의 경험을 깊고 진지하게 되돌아보며 자기이해를 높여 건강한 자 아를 회복할 수 있도록 도와 자기분화의 수준을 높여줄 수 있 도록 돕는 프로그램의 개발 및 실행이 제안된다. 보육교사 보 수교육에서 받는 교육프로그램 안에 이러한 프로그램을 마련 하여 자신을 돌아볼 수 있도록 하고, 보육교사의 심리상담 및 치유를 위한 힐링프로그램을 마련한다면 교사가 자신이 보육 하는 영아와 보다 긍정적인 관계를 많이 맺고, 부정적인 관계 를 감소시킬 수 있는 접근이 될 것이다. 또한 최근 부각되고 있 는 보육교사의 소진을 예방할 수 있는 효율적인 보육프로그램 으로서도 기능할 것으로 기대된다.
본 연구는 보육교사의 원가족 건강성과 자기분화정도가 교 사-영아 간 관계에 미치는 영향력을 상세히 살펴보고 검증함 으로써, 교사-영아 간 관계 증진을 도울 수 있는 요인들을 파 악하였다. 보육교사의 원가족 건강성과 자기분화가 교사-영 아 간 긍정적/부정적 관계에서 각각 다른 양상을 보이면서도 긍정적인 영향력을 미친다는 본 연구의 결과는 보육교사가 자 신의 성장과정을 돌아보는 과정을 통해 자신의 원가족 경험에 대한 인식을 바로 하고 이를 재구성하게 하는 개입과 보육교 사가 건강하게 자기분화를 이룰 수 있도록 돕는 개입이 교사영아 간 관계에 긍정적 영향을 미칠 수 있음을 제시했다는 의 의를 지닌다.

이와 함께, 주양육자인 교사가 영아와 맺게 되는 관계의 특 성 및 영향요인이 부모가 영아 자녀와 맺는 관계의 양상과 유 사함을 증명함으로써 영아와 안정적 애착 관계를 형성하여 영 아의 발달을 돕는 주양육자로서 부모-자녀 관계에 대한 연구 에서 더 나아가 이를 교사-영아 간 관계 및 교사가 영아에게 미치는 영향요인에 대한 연구로 확장하는 것이 필요하며, 부 모-자녀 간 관계에 대해 밝혀진 많은 영향요인들에 대한 연구 결과들이 교사-영아 간 관계에도 적용할 수 있다는 가능성을 보여주는 연구로서의 의의가 있다.

주요 연구결과에 대해 요약 및 논의하여 도출한 결론을 통 해 앞으로 보육교사의 교사-영아 간 관계에 대해 진행될 후속 연구를 위하여 제언하고자 한다. 교사와 영유아의 관계에 대 한 평가로 본 연구에서는 교사가 자기보고를 하였으며 이는 관계의 주관적 속성에 기반 할 때 상당히 신뢰성 높은 조사방 식이다. 그러나 연구의 논의 부분에서 기술한 바와 같이 교사 와 영유아의 개별적인 관계를 측정할 수 있도록 교사가 전체 학급 영유아와의 개별적인 관계에 대한 평정을 하는 방식이나 관찰 방식을 적용하여 실제적인 상호작용에 기반한 관계의 양 상을 분석하는 것이 보다 객관적일 수 있을 것이다. 그리고 이 러한 시도를 통해 교사-영유아 간 개별적인 관계에 영향을 미 칠 것으로 예상되는 영유아의 특성으로서 영유아의 기질, 정 서성 등 개인적 변인의 영향력까지 보다 면밀히 분석하는 연 구를 제안한다. 아울러, 본 연구에서 검증한 원가족건강성과 자기분화는 교사-영아 간 부정적 관계에서의 친밀도에는 영 향을 미치지 않는 것으로 검증되어, 본 연구에서는 교사-영아 간 부정적 관계의 친밀도를 증진할 수 있는 요인에 대한 검증 이 이루어질 수 없었다. 따라서 이에 대한 탐색적 연구를 제안 한다.

이러한 후속연구를 통해 교사와 영아 간의 긍정적 관계를 증진하고 부정적 관계를 개선할 수 있는 다양한 개입 방안이 
마련된다면 교사와 영아 간의 안정 애착 형성을 돕고 궁극적 으로 영아의 건강한 발달을 도모하는 밑거름이 될 수 있을 것 이다.

\section{Acknowledgements}

This study was supported by the 2018 research grant of Sangmyung University.

\section{Notes}

This article was presented at the Autumn Conference of the Korean Association of Child Studies in 2018.

\section{Conflict of Interest}

No potential conflict of interest relevant to this article was reported.

\section{References}

\section{In English}

Anderson, S. A., \& Sabatelli, R. M. (1992). The differentiation in the family system scale (difs). American Journal of Family Therapy, 20(1), 77-89. doi:10.1080/01926189208250878

Bekker, M. H. J., \& van Assen, M. A. L. M. (2006). A short form of the autonomy scale: Properties of the autonomy connectedness scale (ACS-30). Journal of Personality Assessment, 86(1), 5160. doi:10.1207/s15327752jpa8601_07

Birch, S. H., \& Ladd, G. W. (1998). Children's interpersonal behaviors and the teacher-child relationship. Developmental Psychology, 34(5), 934-946. doi:10.1037/0012-1649.34.5. 934

Bowlby, J. (1958). The nature of the child's tie to his mother. The International Journal of Psychoanalysis, 39, 350-373.

Bowlby, J. (1969). Attachment and loss: Volume I. Attachment. New York: Basic Books.

Bowlby, J. (2008). Attachment. New York: Basic Books.

Hamre, B. K., \& Pianta, R. C. (2001). Early teacher-child relationships and the trajectory of children's school outcomes through eighth grade. Child Development, 72(2), 625-638. doi:10.1111/1467-8624.00301

Halford, W. K., Sanders, M. R., \& Behrens, B. C. (2001). Can skills training prevent relationship problems in at-risk couples? Four-year effects of a behavioral relationship education program. Journal of Family Psychology, 15(4), 750-768. doi:10.1037/0893-3200.15.4.750

Howes, C., Hamilton, C. E., \& Philipsen, L. C. (1998). Stability and continuity of child-caregiver and child-peer relationships. Child Development, 69(2), 418-426. doi:10.1111/j.14678624.1998.tb06199.x

Lazarus, R. S. (1981). The stress and coping paradigm. In R. S. Lazarus (Ed.), Fifty years of the research and theory of $R$. $S$. Lazarus: An analysis of historical and perennial issues. New York: Psychology Press.

Kerr, M. E., \& Bowen, M. (1988). Family evaluation. New York: Norton.

Kochanska, G. (2002). Committed compliance, moral self, and internalization: A mediational model. Developmental Psychology, 38(3), 339-351. doi:10.1037//0012-1649.38.3.339

Pianta, R. C. (2001). STRS: Student-teacher relationship scale: Professional manual. Lutz, FL: Psychological Assessment Resources.

Pianta, R. C., \& Steinberg, M. (1992). Teacher-child relationships and the process of adjusting to school. New Directions for Child Development, 1992(57), 61-80. doi:10.1002/ cd.23219925706

Power, T. G. (2004). Stress and coping in childhood: The parents' role. Parenting: Science and Practice, 4(4), 271-317. doi:10.1207/s15327922par0404_1

Sroufe, L. A., \& Fleeson, J. (1986). Attachment and the construction of relationships. In W. W. Hartup \& Z. Rubin (Eds.), Relationships and development (pp. 51-71). Hillsdale, NJ: Lawrence Erlbaum Associates.

Vondra, J., Sysko, H. B., \& Belsky, J. (2005). Developmental origins of parenting: Personality and relationship factors. In T. Luster \& L. Okagaki (Eds.), Parenting: An ecological perspective (2nd ed., pp. 35-71). Mahwah, NJ: Lawrence Erlbaum Associates, Inc.

\section{In Korean}

A, H. S. (2016). The causal relationships among the health of the family of origin, the self-differentiation, and the communication of the married couples and the emotional intelligence of the children. The Journal of Humanities and Social Science 21, 7(3), 415-436. doi:10.22143/HSS21.7.3.22

Cho, B.-S., \& Choi, W.-S. (2013). The correlation between the life satisfaction depending on the attachment types of mothers with young children and their mother-and-child drawings. 
Korean Journal of Art Therapy, 20(4), 689-709.

Choi, I. H. (2012). Relation between parent-child interaction and family-of-origin experience of parents (Master's thesis). Retrieved from http://www.riss.kr/link?id=T13083451

Choi, M.-S., Kong, J.-H., \& Park, E.-Y. (2012). The relationships between maternal child-rearing attitude and children's emotional intelligence and problem behavior. Journal of Parent Education, 4(2), 33-51.

Ha, S.-H. (2007). Intergenerational transmission of the family-oforigin health and self-differentiation (Doctoral dissertation). Retrieved from http://www.riss.kr/link?id=T11007081

Hong, H. K. (2016). The mediating effects of family strength on the relationship between maternal family-of-origin experience and positive parenting behavior to preschooler (Master's thesis). Retrieved from http://www.riss.kr/link?id=T14406738

Hong, K. O. (2001). Relationships among maternal self-perception, parenting behavior, kindergartener's temperament and social competence. Korean Journal of Child Studies, 22(2), 181-194.

Huh, J. H. (2011). Interrelation of the family-of-origin health and parental intelligence (Master's thesis). Retrieved from http:// www.riss.kr/link?id=T12498843

Hwang, H. J., \& Chung, O. B. (2006). A study on mother's attachment to her infant and related factors. The Korean Journal of the Human Development, 13(4), 95-115.

Jang, S.-W. (2008). The influence of family-of-origin experiences on marital intimacy and parent-child relation (Master's thesis). Retrieved from http://www.riss.kr/link?id=T11221123

Jeon, J.-H. (2009). Influence of parents' family-of-origin experience on parenting efficacy and behavior-Focusing on parents with young children-(Master's thesis). Retrieved from http://www. riss.kr/link?id=T11778294

Jeon, Y. J. (2002). The effects of children's coping behavior and threegeneration family experiences on their behavior problems (Doctoral dissertation). Retrieved from http://www.riss.kr/ link?id=T8374575

Ju, J. R. (2015). Correlation between infant-teacher interaction and infants' social, emotional behavior. Global Creative Leader, 8(1), 1-18.

Kim, J. B., \& Kim, J. Y. (2014). Effects of perceptual differences in student-teacher relationships between student and teacher on the level of understanding instructions: Relating with teachers' job satisfaction and students' peer and parental trust. The Journal of Korean Teacher Education, 31(3), 245267. doi:10.24211/tjkte.2014.31.3.245

Kim, K. H., \& Kim, S. H. (2016). The effects of early childhood teacher's self-differentiation and self-efficacy on psychological well-being. The Korea Contents Society, 16(4), 289-300. doi:10.5392/JKCA.2016.16.04.289

Kim, M. H. (2014). The effect of self-differentiation levels of parents on children anxiety: The mediating effect of parent-child communication (Master's thesis). Retrieved from http:// www.riss.kr/link?id=T13414536

Lee, H.-K., \& Lee, E.-H. (2011). The relationship between the self-differentiation levels of parents and behavior problems in their children: The mediating role of marital conflict and conflict coping behavior. Studies on Korean Youth, 22(3), 43-68.

Lee, J. S. (2001). Preschool children's representation of attachment: Associations with teacher-child relationship and social competence (Doctoral dissertation). Retrieved from http:// www.riss.kr/link?id=T8650314

Lee, M. Y. (2014). Effect of emotional intelligence of day-care teachers on teacher sensitivity and teacher-infant relationship (Master's thesis). Retrieved from http://www.riss.kr/link?id= T13732209

Lim, H. S., \& Park, S. Y. (2002). Child's sex, temperament, mother's emotion regulation and parenting as related to child's emotion regulation. Korean Journal of Child Studies, 23(1), 37-54.

Lim, J. Y. (2011). Relationship of the self-differentiation of mothers to their facilitative communicative competency and children's interpersonal relationship (Master's thesis). Retrieved from http://www.riss.kr/link?id=T12343594

Ministry of Health and Welfare. (2017). Daycare and user statistics. Sejong, KR: Ministry of Health and Welfare.

Moon, E.-S., \& Kim, M.-H. (2011). The relationship between mothers' attitudes toward their children's expressiveness, teacher-child relationship and problematic behavior in preschoolers. The Journal of Eco-Early Childhood Education, $10(2), 59-81$.

Moon, J. Y. (2014). The impacts of infant's temperaments and teacher's emotional expressivity on relationship between infants and teachers (Master's thesis). Retrieved from http://www. riss.kr/link?id=T13598958

Mun, Y. H. (2013). The influence of mothers' family-of-origin health and self-differentiation on parenting efficacy and parenting attitude (Master's thesis). Retrieved from http://www.riss. $\mathrm{kr} /$ link?id=T13169858

Oh, J. A. (2007). A study on mother's adult attachment, empathy ability and parent-child relationships (Master's thesis). Retrieved from http://www.riss.kr/link?id=T10989693

Oh, J.-Y. (2016). The effect of self-differentiation on parenting stress of mothers: Mediation effect of stress coping strategies, marital intimacy (Master's thesis). Retrieved from http://www.riss. $\mathrm{kr} /$ link?id=T14194512

Park, H. S., \& Suh, J. H. (2017). The effects of childhood experience on teacher sensitivity: A mediational effect of self-differentiation. The Korean Journal of the Human Development, 24(4), 17-40. doi:10.15284/kjhd.2017.24.4.17

Park, M. J. (2011). Bumoui jaabunhwa sujune ttareun janyeoui 
uisasotong yubyeong yeongu [부모의 자아분화 수준에 따 른 자녀의 의사소통 유형 연구](Master's thesis). Retrieved from http://www.riss.kr/link?id=T12368032

Park, S.-M. (2013). The relation among the emotion-regulation ability, child-teacher relationship burnout of early childhood teachers. The Journal of Child Education, 22(1), 21-32.

Song, M. S., \& Kim, S. Y. (2009). The relationship between emotional intelligence and job stress as perceived by child care teachers. Journal of Future Early Childhood Education, 16(4), 99-119.

Song, S. J. (2015). The effects of family-of-origin experiences and marital satisfaction on parenting behavior among mothers of preschool-aged children (Master's thesis). Retrieved from http://www.riss.kr/link?id=T13669007

Song, J. A. (2018). Mediating effect of family elasticity in the relationship between family-of-origin experiences and maternal parenting stress. Journal of Parent Education, 10(4), 31-53.

\section{ORCID}

Hyun Soon Park http://orcid.org/0000-0003-3469-8462

Joo Hyun Suh http://orcid.org/0000-0001-6953-4420

Received February 28, 2019

Revision received March 21, 2019

Accepted April 15, 2019 